\title{
The Effectiveness of Analyzing Design Works in Developing the Artistic Taste for the Secondary Stage Students
}

\author{
Prof. Dr. Aad Mahmood Hamady \\ Asst. Prof. Dr. Namer Kasim Khalaf \\ College of Fine Arts \\ University of Diyala \\ Department of Plastic Arts
}

\begin{abstract}
The Artistic Taste Is Considered As One Of The Aspects Which The Iraqi Education Ministry Attempts To Achieve Through Implementing The Artistic Education Programs In The Materials And Curriculums Of The Secondary Schools. Hence, We Must Give Attention With This Aspect And Developing The Basis Which Contributes In Achieving It. On Top Of This, Comes Overcoming The Problem Low Standard Of The Artistic Taste Which Became A Dire Necessity Which Puts The Current Study In Front Of The Correct Scientific Steps In Adopting This Need.The Research Aimed At Identifying The Effectiveness Of Analyzing Design Works In Developing The Artistic Taste For The Secondary Stage Students; In Addition To The Variations In The Artistic Taste Between The Male And Female Students At This Secondary Stage. The Study Included Two Samples From The Fifth Secondary Class Students Where The First Sample Was An Experimental Sample Whereas The Second Sample Was A Control Sample. The Number Of Students In Each Sample Equal (30) Male And Female Students That Is (15) Male Students And (15) Female Students For Both Samples For Both Experimental And Control Samples. This Study Used The (Artistic Taste Test) As A Research Tool Prepared In Year 2010 For The Universities Colleges Students.

The Two Researchers Adjusted This Test To Conform To The Secondary Stage Students And According To The Well-Known Controls In The Scientific Research. For This Test New True And Steady Coefficient Were Invented Where It Was Possible To Use And Implement This Test On The Secondary Stage Students. Also, The Research Was Performed Through The Use Of Statistical Means Which Were Suitable To Extract The Results. The Study Reached The Following Group Of Results Including:The Experimental Sample Which Used (Analysis Of The Design Works) Was Superior To The Control Sample With Statistical Significance Equals (0.05). The Study Also Concluded That There Are Differences Between Male And Female Students In The (Artistic Taste) Variable At Significance Level Of (0.05).

The Research Reached Several Conclusions Such As The Artistic Taste For The Secondary Stage Students Can Be Developed By The Method Of Analyzing The Design Works.

The Two Researchers Reached Several Recommendations Such As Using The (Analysis Of The Contents) As A Teaching Strategy In Teaching The Secondary Stages Students In The (Artistic Education) Subject.
\end{abstract}

Key Words: Effectiveness, Design Work, Development, Artistic Taste

\section{First: Research Methodology:}

Research Problem: The Artistic Taste Is One Of The Aspects Which The Artistic Education In The Secondary Schools Attempts To Achieve Where The Aim Of The Artistic Education Is To Achieve An Esthetical Artistic Taste By The Students. The Two Researchers Deliberately Performed Research And Explanatory Studies On The Secondary Stage Students In The Scope Of The Artistic Education In The Scope Of The Artistic Education, They Found That The Secondary Stage Students Find Difficulty In Tasting The Artistic Works In General Especially In The Subjects Of Drawing And Design. This Was Proved By The Teachers Who Perform Research And Applied And Experimental Studies In The Stage Of Studying The Master And Doctorate Where Most Of Them Diagnose Many Deficiencies On This Aspect And Realized That The Secondary Stage Students Suffer From Great Difficulty In Tasting The Artistic Works Especially The Drawing And Design. Hence, The Following Questionnaires Were Faced By The Researchers Such As: 
1.What Is The Standard Of The Artistic Taste For The Secondary Stage Students !

2.Is It Possible To Develop The Artistic Taste For The Secondary Stage Students Through Analyzing Design Works In Front Of Them?

3.Does The Sex Variations Has An Influence In Developing The Artistic Taste Using Designed Works Analysis ?.

Therefore, The Two Researchers Specified The Subject Of Their Studies As : (Effectiveness Of Analysis The Designing Works In Developing The Artistic Taste For The Secondary Stage Students).

Research Importance: The Importance Of This Research Is As Follows:

1.According To The Researchers, This Is The First Study Which Covers Developing The Artistic Taste For The Secondary Stage Students Using Analyzing Designing Works.

2.The Current Study Contributes In Assisting The Specialists In The Artistic Education In The Education Authorities Because They Contribute In Developing The Artistic Taste For The Secondary Stage Students Which Assist Them In Achieving The Most Important Objectives For Teaching The Artistic Education I.E. (Artistic Taste).

3.This Study Forms An Additional Knowledge Where Its Results Were In The Scope Of The Specialty Of The Artistic In General And The Artistic Education In The Secondary Stage In Particular.

4.The Current Study Opens New Horizons As It Will Give Incentives To Others In Trying Other Methods Which Differ Than The Analysis Of Design Works.

5.Using The Method Of Analysis Of The Design Works In Developing The Artistic Taste Is Considered As A New Method Which Aims At Giving The Information And Searching For It In The Design Work.

Research Objectives: The Research Aimed At The Following:

Effectiveness Of Analyzing Design Works In Developing The Artistic Taste For The Secondary Stage Students.

The Variations In The Artistic Taste Between The Male And Female Students In The Experimental Sample.

Research Hypotheses:

(There Are No Statistical Significance Differences At The Level Of (0.05) Between The Average Experimental And Control Samples Individuals Marks In The Artistic Taste In The Pre-Test).

(There Are No Statistical Significance Differences At The Significance Level Of (0.05) Between The Average Experimental And Control Samples Individuals Marks In The Artistic Taste In The Post-Test).

(There Are No Statistical Significance Differences At The Significance Level Of (0.05) Between The Average Students Marks And Average Female Students Marks In The Experimental Sample In The Artistic Taste In The Post-Test).

\section{Second: Theoretical Background \& Previous Studies:}

The Importance Of Studying The Artistic Taste:

The Artistic Taste Is A Feature Which Occupied Generations Of Intellects And Philosophers Since Plato Until Now. (Webster) Dictionary Stated That The Taste Is An Action And Which Is The Ability To Distinguish Between The Beautiful Thing From The Ordinary Thing; Or The Potential To Deduce What Is Beautiful In The Art And The Nature; Or The Growth Of The Individual Sensitivity When Tasting (Fadly, 2010. Page:4).

Al-Basyoni Stated That The Word (Taste) Means The Aesthetical Individual Response To The External Factors (Al-Basyoni , 1985, Page:93).The (Artistic Taste) Is One Of The Factors Influencing The Optical Arts And Which Covers Talking About Various Types Of The Arts Including The Art Of Design Through Describing, Analyzing, Evaluating And Judging It So That It Will Be Clarified To Those Who Receive The Art. This Is In Addition Implementing The Artistic Values In Producing Their Designing Works (Al-Shahin, 2006, Page: 19). The Artistic Taste Means The Potential Or An Educational Target Which Is Done Through Training The Learner To Enjoy What He Realizes Of Moral Or Material Subjects And Feeling Happy Towards Them. This Is Considered As A Main Target For The Arts Education Lessons Which Aims At Creating Taste For The Learners To Perform The Works And The Accuracy Of The Thoughts And The Beauty Which Exists In The Nature. These Things Incite The Feeling Of Beauty And The Enjoyment. 
Here, We Must Concentrate On The Learner Potential On Coping With The Relationships Between The Elements Where The Potentials Are The Objectives When The Learner's Target Is To Develop The Taste (Al-Moneif \& Salih, 1988, Page: 38).

Therefore, The Artistic Taste Is The Process Of Building The Values Which The Taster Attempts To Unveil It By Analysis, Explanation And Estimation Which Grows In The Light Of The Good Understanding And The Good Judgment On The Esthetical Aspects In The Artistic Shape (Labd, 1999, Page:70).

There Is A Necessity Imposed By The Need Of The Learner To Study The Artistic Taste Whose Importance Is As Follows:

1.The Artistic Taste Enriches The Esthetical Expertise For The Learner, And Develops The Optical Realization And The Values Of Beauty In The Life And Art.

2.The Artistic Taste Is Considered As A Real Path For The Individual To Reach Creativity Or The Creative Process.

3.Tasting The Beauty Enriches The Feelings And The Behaviors And Link The Thoughts Of The Taster With The Creators Which Were Created By God In This Universe.

4.Through Taste, There Is A Type Of Language Which Makes Nations And Societies Close To Each Other In Order To Understand The Beauty And Art.

5.The Artistic Taste Supports The Thoughts Of The Taster And Makes It Easier For Him Reading And Analyzing The Optical Symbols And Promoting His Behavior. (Al-Shahin, 2006, Page:27).

The Contemporary Concept Of The Artistic Taste Became A Type Of The Creative And Esthetical Behavior Which Promotes The Love Of Knowledge And The Accuracy Of Observation And The Seriousness Of The Selection And Comparing The Things And Judging Them. These Thoughts Support The Scientific Personality And Support The Individuals' Behaviors And Methods In The Vision, Knowledge And Research. They Differ A Lot If The Individual Was Un-Trained On The Artistic Taste. (Rosenthal, 1996) Sees That The Artistic Taste Is A Psychological And Emotional Case Which Depends On The Aesthetical Realization With The Features Which May Be Linked To The Mysterious Reality (Rosenthal, 1996, Page:11).

The Artistic Taste Can Be Considered A Communication Process Or Suitable Between The Following Three Parties:

The First Party: The Artist Who Is Represented In His Design Works.

The Second Party: The Enjoyer

The Third Party: The Artistic Work Which Forms With The Aesthetical Taste, Two Faces For One Currency Which Are Shared By The History Of Art.

Therefore, We Can Say That The Artistic Taste Process Is Based On Several Essential Elements So That The Artistic Taste Circle Can Be Completed Where It Was Classified As Follows:

First: The Artistic Work: This Is The Creative Work Produced By The Innovator And Reflects The Reality According To The Conditions And Factors Surrounding The Work.

Second: The Artist: He Innovates Or Produces The Artistic Work Where The Artistic Work Vary From One Artist To Another According To The Artistic Method Which He Follows.

Third: The Taster: He Is The Individual Who Enjoys And Sympathizes A Certain Artistic Work. This Response Is An Esthetical Response

Fourth: The Critic: This Individual Owns High Technical Culture And Has The Potential To Study, Analyze And Describe The Artistic Work. He Has A Strong Proof And Evidence To Support His Neutralized Judgment. He Also Has The Potential To Persuade And Showing The Positive And Negative Aspects In The Designing Work For The Artist. (Al-Shahin, 2006, Page:38).

In General, The Artistic Taste Is Considered As The Most Important Objectives Of The Arts Education Subject Where The Artistic Experiences Acquired By The Learners Develop Their Potential In Tasting The Creative Human Expressions; Where The Learner Has No Sufficient Feeling For The Beauty As Nothing Has Owns Has A Meaning And The Taste Must Be Acquired By The Learner Himself Through The Practice And Merges In The Subjects Which He Wants To Taste. This Includes The Knowledge In Which The Learner Must Try Hard To Learn It (Freij, 2000, P:63-64). 


\subsection{Developing The Artistic Taste:}

The Importance Of The Artistic Taste Is Because It Is A Process For Building The Values Which The Taster Attempts To Discover It By Analysis, Explanation And Estimation Which Grows In The Light Of The Good Understanding And The Descent Judgment On The Esthetical Aspects In The Artistic Shape (Lebd, 1990, Page:70). The Receiver Of The Artistic Works Assumes That He Gained Some Training Of The Thoughts And Feelings So That He Interacts Through Internal Innovation With The Things. The Experience Of The Artist Resembles That Of The Taster Who When Accepts Watching The Artistic Work As If He Looks Through A Window Prepared For Him By The Designer Artist During His Excellence Of His Work Attempting Repeating For Himself The Sequence Of The Technical, Moral And Mental Operations Which The Designer Went Through During Performing His Work. (Al-Fadly, 2010, Page:4).

The Taster Is Assumed To Have An Excellent Dialogue Language And A Suitable Artistic Culture So That He Understand The Structures Of The Artistic Work And Sinks Inside Its Esthetical Structures And Passes Through The Same Creative Artistic Experiment Of And Attempts To Follow The Artist's Creative Path As He Tries To Preserve The Direction During Tasting The Stages Of The Artist Work Whether It Was Visible Or Audible Or Readable. (Yehya,1992, Page:10).

2.2 Effectiveness Of Analyzing The Designing Works

The Effectiveness Of Analyzing The Design Works Is A Process Which Depends On A Group Of The Factors And Variables Elated To The Reading Of The Design (Picture Or Portrait) Because It Is A Compound Process Which Includes Many Of The Mental Processes. It Also Has Levels Because The Process Of Analysis Or Reading Is Considered As A Process Of Resolving The Message Puzzle Symbols Reaching The Meaning. The Process Of Solving The Symbols Includes The Following Two Steps: Distinction \& Explanation (Abd AlMoneim, 2000, Pages:88-90). There Are Several Imaginations For The Levels Of Analyzing The Designed Works And The Drawings Where Some Point At Existence Of The Following Three Levels For Analyzing The Design:

1.Level Of Counting: Which Sees The Designed Work In The Individual, So Counts Its Contents.

2.Level Of Description: The Learner Describes The Elements Of The Designed Work Showing The Features Of Its Parts.

3.Level Of Explanation: Here, The Individual Finds A Relationship Between The Design Elements And So They Are Linked Together In A Certain Concept.

4.(Al-Jazar) Stated That Reading The Picture Which Is Represented In Our Current Research By (Designed Works). The Illustrative Drawings Include That The Learner Performs The Several Operations (Al-Fadly, 2010, Page:69):

5.Observing And Describing The Contents Of The Design.

6.Explanation Of The Information Included In The Design.

7.Making Acceptable Conclusions.

8.Evaluating The Information Concluded From The Design And The Clarifying Drawing.

The Following Are The Processes And Patterns Of Behaviors Which Must Be Practiced During Dealing With The Designed Work And The Pictures:
1)Explanation, 2) Understanding,
3) Comparison,
4) Sequencing, 5) Realizing The Relationships, 6)
Explanation.

Hence, There Is The Need To Use The Designed Works And The Drawings And The Necessity To Develop Their Reading Skills And Analyzing Them By The Learners As They Are Useful For Them On The Following Aspects:

1.On Concentrating The Attention, Thinking And The Gaining The Knowledge.

2.Developing The Artistic Taste For The Learners. (Al-Fadly, 2010, Page:69).

For The Designed Artistic Work To Become Effective, It Must Be Based On Factors And Principles Favorable To The Taster. Among These Principles Is The Principle Of Membership In The Designed Work Where This Unit Is The Linking Between The Parts Of The Designed Work. But In The Forms Of The Contemporary Design, The Direct Idea May Disappear Because There Is No One Central Point. Among The Other Principles Is The Principle Of Diversity Where The One Design Subject May Have Reactions, Repetitions And Variations. 
The Same Thing Applies To The Principles Of Equilibrium And Similarity Or The Principle Of Conformity Between Various Shapes And The Principle Of Moving From Time Units Or Parts To Later Parts Which Are Infiltrated By Periods Or Quietness Also The Movement And Diversity. These Are Considered As General Principles For The Design Work Which Face The Taster And Results In The Aesthetical Response (Jamagh, 2016, Pages: 827-828). Finally, On This Subject, We Can Say That The Artistic Education Contributes With The Remaining Study Subjects In Developing The Students Preparations And Directing Them Towards The Descent Social And Cultural Direction. The Artistic Education Improves The Taste And Is An Important Mean Of Knowledge. (Herbed Reed) Stated That The Art Is One Mean Of The Means Of Knowledge And That The World Of Art Is An Order Of Knowledge Whose Value For The Human Is Not Less Than The World Of Philosophy (Al-Robaey, 2015, Page:177).

\subsection{Previous Studies:}

The Two Researchers Performed Investigations And Searching In The Literatures And In The Specialized Scientific References Including The Research And Studies Which Covered The Scope Of Effectiveness Of Analyzing The Artistic Portraits Or Developing The Artistic Tasting. The Two Researchers Found A Number Of Research And Previous Studies Related To Some Subjects Of The Current Studies Especially Its Theoretical Aspect. Examples Of These Studies And Research Which Are Not Linked Directly To The Current Study Are (Al-Fadly, 2010) Study Titled "The Culture Of The Picture And Its Role In Enriching The Artistic Taste For The Reliever"; And The Study By (Al-Robeay, 2015) Titled "Relationship Between The Artistic Taste With The Study Of The Artistic Education Subject In The Iraqi Schools - Babylon Governorate); And The Study By (Abd Al-Mohsen \& Al-Zarb, 2016) Titled "Relationship Between The Artistic Taste With The Study Of Art For The Fine Arts College Students, University Of Babylon " And The (Jomagh, 2016) Study Titled "The Effectiveness Of The Individual Learning Strategy In Developing The Artistic Taste For The Artistic Education Department Students" And Other Scientific Studies Which Were Useful For The Two Researchers And Which Promotes Achieving The Targets Of The Current Study. This Way, The Two Researchers Didn't Find Any Previous Study Which Conforms With The Current Study And Therefore They Just Pointed Out To This Point.

\section{Third: Research Methodology \& Its Procedures:}

1.Research Methodology: The Current Study Were Performed Using The (Experimental Research Methodology).

\section{Research Procedures:}

First: Research Population: The Current Research Population Was Limited To The Fifth Classes' Students In The Secondary Study In Diyala Governorate Including Their Various Branches. The Number Of These Students Were (16933) Male And Female Students And (8370) Students Distributed Over (251) Secondary Students Which Include (20) Schools In Only Baquba City Based On The Statistics Done By The General Authority For Education In Diyala Governorate (Iraq) For The Study Year (2018 / 2019).

Second: Research Samples: The Current Work Was Performed By Using Three Samples. The First Sample Is For The Questionnaire Study Whereas The Second And Third Sample Are For The Main Study As Follows:

The Questionnaire Study Sample: This Sample Contained (120) Male And Female Students I.E. (60) Male Students And (60) Female Students Who Were Taken Using A Random Method From Two Schools For Boys And Two Schools For Girls. This Sample Was Used In The Validation Of The True Procedures.

Table (1)

\begin{tabular}{|c|c|c|c|c|c|c|c|c|c|}
\hline$\frac{\text { Sex And Type Of Study }}{\text { \& Sum }}$ & Ma & & & & Fem & & & & \\
\hline Sample Nature & 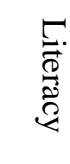 & $\frac{\frac{d}{2}}{\frac{D}{2}}$ & 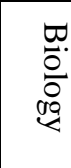 & $\begin{array}{l}\overrightarrow{0} \\
\ddot{D}\end{array}$ & 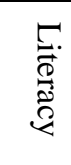 & $\frac{\vec{D}}{\frac{D}{0}}$ & 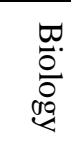 & $\overrightarrow{\stackrel{0}{\Xi}}$ & Total Sum \\
\hline Study Sample Questionnaire & 20 & 20 & 20 & 60 & 20 & 20 & 20 & 60 & 120 \\
\hline The Experimental Sample & 5 & 5 & 5 & 15 & 5 & 5 & 5 & 15 & 30 \\
\hline The Control Sample & 5 & 5 & 5 & 15 & 5 & 5 & 5 & 15 & 30 \\
\hline
\end{tabular}

Study Sample Based On The Value Nature Variables, Study Branches And The Total 
a.The Experimental Sample: This Experimental Sample Consists Of (30) Male And Female Students From The Fifth Secondary Classes Students Who Were Taken Randomly From A Boys School And From A Female School From All Branches. The Sample Consisted Of (15) Male Students And (15) Female Students Where Each Consisted Of (5) Male Or Female Students For Each Study Branch. The Main Study Was Performed In These Two Schools As Shown In Table (1).

b.The Control Sample: This Control Sample Consisted Of (30) Male And Female Students From The Fifth Secondary Classes Students Who Were Taken Randomly From Both Schools From Which Was Taken The Experimental Sample. The Sample Consisted Of (15) Male Students And (15) Female Students Where Each Consisted Of (5) Male Or Female Students For Each Study Branch As Shown In Table (1).

\section{Third: The Experimental Design:}

To Perform This Current Study, The Experimental Design With The Two Samples I.E. (Experimental \& Control) Were Used Which Have The (Pre) And (Post) Tests And The Fixed Control As Shown In Table (2).

Table (2)

\begin{tabular}{|c|c|c|c|c|c|}
\hline \multirow{2}{*}{$\begin{array}{c}\text { Fifth Secondary } \\
\text { Classes Students With } \\
\text { All Its Branches. }\end{array}$} & Group & (Pre) Test & Method & $\begin{array}{c}\text { (Post) } \\
\text { Test }\end{array}$ & $\begin{array}{c}\text { Dependent } \\
\text { Variable }\end{array}$ \\
\cline { 2 - 5 } & Experimental & $\mathrm{X}$ & $\begin{array}{c}\text { Analysis Of Designed } \\
\text { Works (Printed). }\end{array}$ & $\mathrm{X}$ & \multirow{2}{*}{ Artistic Taste. } \\
\cline { 2 - 5 } & Control & $\mathrm{X}$ & Ordinary Method & $\mathrm{X}$ & \\
\hline
\end{tabular}

The Experimental Design Used In The Current Research

Fourth: The Research Tool: The Current Research Was Performed One Research Tool I.E. (Artistic Taste Test) Prepared By (Al-Gezany) In Year 2010. The Study Used (Artistic Taste \& Its Relationship With The MultiIntelligence For The Main Education College Students).

1.Artistic Taste Test: The Test Consisted Of (15) Questions Where There Is In Each Question One Or More Picture Under Which The Researcher Placed A Group Of Questions Which Ranged Between One And Four Questions. The Student Must Answer Them Where The Number Of The Questions In The Test Were (48) Questions. Since The Test Was Designed For The College Students And The Sample Of The Study Is The Secondary Stage Students, Therefore This Must Be Adapted To The Secondary Stage Students. This Necessitates Extracting Difficult Coefficients In Addition To Distinction Coefficients For The Test Paragraphs.

2.Difficulty Coefficients \& Distinction Of The Test Paragraphs: The Difficulty Coefficients Were Calculated For Each Of The Test Paragraphs After Implemented On (120) Male And Female Students Who Are The Sample Of The Questionnaire Study In The Current Study. The Statistical Analysis Showed That There Are (3) Test Paragraphs Which Were Distinguished By Very Difficult Coefficients Equaled (0.891, 0.086, 0.84) Respectively. Therefore, The Two Researchers Had To Expel These Test Paragraphs. As For The Remaining Test Paragraphs, Their Difficulty Coefficients Ranged Between (0.23, 0.69) Where They Are Accepted Difficult Coefficients Because They Lied Within A Range Of Approximately (0.20) And Hence The Test Consisted Of (45) Paragraph.

3.Distinguishing The Paragraphs: Showing The Distinction Of The Paragraphs Is Considered Among The Important Aspects In The Test Because This Shows The Effectiveness Of These Paragraphs In The Distinction Between The Individuals In The Side Measured By The Test. Therefore, The Two Researchers Had To Calculate The Distinction Coefficients For The Remaining (45) Test Paragraphs Using The Method Of Comparison For The Questionnaire Study Sample Individuals Marks Consisting Of (120) Male And Female Students I.E. (60) Male Students And (60) Female Students. For Each Of The Test Paragraphs.

If Their Marks Were Ordered In Descending Order And If Selected The Upper Percentage (27\%) And The Lower (27\%) Which Equals (32) Male And Female Students For Each Of Them (Highest 32 Marks) Upper Category Triangle And (Lowest 32 Marks) Lower Category Triangle. Then, The (T) Values For All The Test Paragraphs Ranged Between $(2.11$ \& 2.94) Which Was Statistically Significant At (0.05) Level Where The (T) Value Is (1.67) At Degree Of Freedom Equals (62). Therefore, The Test With Its (45) Paragraphs Can Be Applied To The Secondary Stage Students. 
1.Validity Of The Paragraphs: The Validity For Each Of The Test Paragraphs Was Calculated Through Its Relationship With The (Total Mark For The Test). The Coefficients Of Correlation (Pearson) Were Calculated For The Marks Of Each Paragraph With The (Total Mark For The Test), Where It Was Found The Values Of The Coefficients Of Correlation Ranged Between (0.346 \& 0.514) Where All These Values Have Statistical Significance At (0.05) \& (0.01) Which Was Concluded That All The Test Paragraphs Are Valid Experimentally.

2 Validity: The Distinction Of The Test Paragraphs Can Be Considered As A Pointer To The Validity Of The Test. Therefore, The Two Researchers Used This Phenomenon As A Pointer For The Validity Of The Test

3.Test Steadiness: The Test Steadiness Was Obtained By Repeating The Action Called (Re-Testing) Where The Two Researchers Took (50) Tests Randomly From The Questionnaire Study Tests. Then, They Repeated The Test After (14) Days On The Same Individuals The Coefficient Of Correlation (Pearson) Was Calculated Between The Marks Of The Two Attempts As Its Value Equals (0.852). This Coefficient Has Significance At The Levels (0.5) \& (0.01) Which Points Out That The Test Is Very Steady. Therefore, The Test Became Valid And Steady And Became Possible To Be Used In The Current Study On The Secondary Stage Students.

4.Rewarding The Main Study Samples: The Two Researchers Rewarded The Individuals Of The Main Study Samples I.E. (Experimental \& Questionnaire) In The Age And Previous Experience (Artistic Taste) Variables Based On The Following:

5.Rewarding The Ages: The Two Researchers Calculated The Students' Ages In Months Until 8/4/2019 Where (T) Value Was Calculated. Its Value Was (0.080) Which Was Less Than The Tabulated (T) Which Equals (1.672). This Implies That The Individuals Of The (Experimental) And (Control) Samples Are Equivalent By Age Because The Value Of The Calculated (T) Value Is Not Statistically Significant At (0.05) As Shown In Table (3).

\begin{tabular}{|c|c|c|c|c|c|c|}
\hline Arithmetic Mean \& & \multirow{2}{*}{$\begin{array}{c}\text { No. Of } \\
\text { Individuals }\end{array}$} & \multirow{2}{*}{$\begin{array}{l}\text { Arithmetic } \\
\text { Mean In } \\
\text { Months }\end{array}$} & \multirow[t]{2}{*}{ Variation } & \multicolumn{2}{|c|}{ (T) Value } & \multirow{2}{*}{$\begin{array}{c}\text { Statistically } \\
\text { Significant } \\
(0.05)\end{array}$} \\
\hline Nature Of Sample & & & & Calculated & Tabulated & \\
\hline $\begin{array}{c}\text { Experimental } \\
\text { Sample. }\end{array}$ & 30 & 210.8 & 5.808 & \multirow[t]{2}{*}{0.080} & \multirow[t]{2}{*}{1.672} & \multirow[t]{2}{*}{$\begin{array}{c}\text { Non- } \\
\text { Significant }\end{array}$} \\
\hline Control Sample & 30 & 211.1 & 6.656 & & & \\
\hline
\end{tabular}

Ages Of The Experimental \& Control Samples Individuals And Variations And The Calculated (T) Value And Its Significance.

Rewarding The Previous Experience (Artistic Taste) \& Pre-Test First Hypothesis: The Two Researchers Awarded The Individuals Of The Experimental And Control Study Samples In The Artistic Taste Where Their Arithmetical Means In The Artistic Taste Were Calculated For Them Covering The Variations And (T) Value Was Calculated Were Its Value (0.97) Was Less Than Its Tabulated (T Value) I.E. (1.672). This Means That That It Had No Statistical Significance At (0.05) Level. Hence, The Individuals Of The Two Samples Were Equivalent On The Previous Experience (Artistic Taste) And Hence The First Hypothesis Is Accepted.

\begin{tabular}{|c|c|c|c|c|c|c|}
\hline Arithmetic Mean \& & \multirow{2}{*}{$\begin{array}{c}\text { No. Of } \\
\text { Individuals }\end{array}$} & \multirow{2}{*}{$\begin{array}{c}\text { Arithmetic } \\
\text { Mean In } \\
\text { Months }\end{array}$} & \multirow{2}{*}{ Variation } & \multicolumn{2}{|c|}{ (T) Value } & \multirow{2}{*}{$\begin{array}{c}\text { Statistically } \\
\text { Significant } \\
\quad(0.05)\end{array}$} \\
\hline Nature Of Sample & & & & Calculated & Tabulated & \\
\hline Experimental Sample. & 30 & 19.02 & 7.728 & & & \\
\hline Control Sample & 30 & 18.98 & 7.617 & 0.070 & 1.672 & $\begin{array}{c}\text { Non- } \\
\text { Significant }\end{array}$ \\
\hline
\end{tabular}

Degree Of Freedom $=58$

Table (4)

Arithmetical Means And Variations In The Artistic Taste For The Main Study Samples And The (T) Value And Its Significance. 
6.The Main Study: After The Two Researchers Verified Their Research Tool And Its Availability For The Secondary Stage And Rewarding The Main Study Samples In The Age And Experience Variables, Then The Two Researchers Started Performing The Main Study Which Lasted For Five Weeks I.E. From 1/3/2019 Until 8/4/2019 As Follows:

1.The Experimental Sample: The Two Researchers Gave Lectures To This Sample's Individuals In The Subject Of Elements And Basis Of Design Using Analysis Of Designed Works At The Rate Of One Portrait In Each Lesson. This Lasted For Five Weeks At Rate Of Two Lessons Every Week And Therefore The Number Of Lessons Became Equal Ten Lessons.

2.The Control Sample: The Two Researchers Gave Lectures To This Sample's Individuals In The Subject Of Elements And Basis Of Design Using Lectures Which Lasted For Two Lectures Weekly Where The Subject Of Each Lecture Is The Subject Itself Taken By The Experimental Sample But Without Utilizing From Analyzing Designed Works For This Sample. Therefore, The Number Of Lessons Became Equal (10).

7. The Statistical Means: The Two Researchers Used The Statistical Package (SPSS) Where The Following The Following Statistical Means:

- (T) Test For Two Independent Samples Where The Actions Were Used To Differentiate The Test Paragraphs And Rewarding The Two Samples In The (Age) And (Previous Experience).

- Correlation Coefficient (Pearson) Which Used The Steadiness Of Test.

- Coefficient Of Difficulty For The Test Paragraphs.

Fifth: Discussion Of The Research Results:

The Research Results: The Statistical Analysis Of The Main Study Information Used The Following Hypotheses:

First Hypothesis: (There Are No Statistically Significant Differences At (0.05) Significant Level Between The Average Marks Of The Experimental And Control Sample Individuals In The Artistic Taste In The Pre-Test). Then, Verifying It In The Research Procedures When The Experimental And Control Study Samples Were Rewarded. Therefore, This Hypothesis Is Accepted.

Second Hypothesis: (There Are No Statistically Significant Differences At (0.05) Level Between Average Marks Of The Experimental Sample Individuals And The Average Marks Of The Control Sample Individuals In The Artistic Taste In The Post-Test).

The Statistical Analysis Showed That There Are Statistically Significant Differences At (0.05) Level Between The Average Marks Of The Experimental Sample And The Control Sample In The Artistic Taste. This Is Resulted From An Increase In The Average Marks Of The Experimental Sample Individuals And The Calculated Value Of (T) Equals (12.576); Whereas The Tabulated (T) Value Equals (1.672). Therefore, The Calculated (T) Value Is Much Greater Than The Tabulated (T) Value. Hence, The Second Zero Hypothesis Is Rejected.

\begin{tabular}{|c|c|c|c|c|c|c|}
\hline Arithmetic Mean & \multirow{2}{*}{$\begin{array}{l}\text { No. Of } \\
\text { Individuals }\end{array}$} & \multirow{2}{*}{$\begin{array}{l}\text { Arithmetic } \\
\text { Mean }\end{array}$} & \multirow{2}{*}{ Variation } & \multicolumn{2}{|c|}{ (T) Value } & \multirow{2}{*}{$\begin{array}{c}\text { Statistically } \\
\text { Significant At } \\
(0.05) \text { Level. }\end{array}$} \\
\hline Nature Of Sample & & & & Calculated & Tabulated & \\
\hline $\begin{array}{c}\text { Experimental } \\
\text { Sample. }\end{array}$ & 30 & 24.8 & 8.88 & \multirow[t]{2}{*}{12.576} & \multirow[t]{2}{*}{1.672} & \multirow{2}{*}{ Significant } \\
\hline Control Sample & 30 & 19.04 & 8.179 & & & \\
\hline
\end{tabular}

Average Of The Experimental \& Control Sample In The Artistic Taste, Variations \& (T) Values \& Their Significance.

Third Hypothesis: (There Are No Statistically Significant Differences At The (0.05) Level Between Average Male Students Marks And Average Female Marks In The Experimental Sample In The Artistic Taste In The PostTest). The Statistical Analysis Showed That There Are No Statistically Significant Differences Between Average Male Students' Marks And Average Female Students' Marks In The Experimental Sample In The Artistic Taste In The Post-Test Where The Value Of Calculated (T) Equaled (1.75) Which Is The Value Of The Tabulated (T) 
Which Equals (1.701). Therefore, The Difference Has No Significant Value And Hence The Zero Hypothesis Is Accepted As Shown In Table (6):

\begin{tabular}{|c|c|c|c|c|c|c|}
\hline $\begin{array}{l}\text { Arithmetic } \\
\text { Mean \& (T) }\end{array}$ & \multirow{2}{*}{$\begin{array}{c}\text { No. Of } \\
\text { Individuals }\end{array}$} & \multirow{2}{*}{$\begin{array}{l}\text { Arithmetic } \\
\text { Mean In } \\
\text { Months }\end{array}$} & \multirow{2}{*}{ Variation } & \multicolumn{2}{|c|}{ (T) Value } & \multirow{2}{*}{$\begin{array}{c}\text { Statistically } \\
\text { Significant } \\
(0.05)\end{array}$} \\
\hline $\begin{array}{l}\text { Nature Of } \\
\text { Sample }\end{array}$ & & & & Calculated & Tabulated & \\
\hline Male Students & 15 & 24.11 & 8.56 & \multirow[b]{2}{*}{1.057} & \multirow[b]{2}{*}{1.701} & \multirow{2}{*}{ Non-Significant } \\
\hline $\begin{array}{l}\text { Female } \\
\text { Students }\end{array}$ & 15 & 24.05 & 8.32 & & & \\
\hline
\end{tabular}

Degree Of Freedom $=28$

Table (6)Average Male \& Female Students In The Experimental Sample In The Artistic Taste In The (Post) Test, Variations \& (T) Values And Their Statistical Significance.

Discussing The Research Results:

Referring To Table (5), We Find That Average Marks Of The Experimental Sample Individuals Is (5) Degrees More Than The Average Marks Of The Control Sample Individuals. To Confirm This Increase, We Find That The Value Of The Calculated (T) Equals (12.576) Which Is Much Greater Than The Value Of Tabulate (T) Which Implies That The Difference Is Statistically Significant At (0.5) Level.

The Increase In Average Marks Of The Experimental Sample Individuals In The Artistic Taste In The Post Test Points At That Their Artistic Taste Increased By These Lectures Which Used Analyzing Designed Works With Positive Increase Equals (5) Marks Which Means The Effectiveness Of Analysis Of Designed Works In Developing Their Artistic Taster Where It Was In The Post Test Equals (19.02) And Became In The Post Test Equals (24.8) As Shown In Table (5).

Looking At Table (6), We Find That There Are Statistically Significant Differences At (0.05) Level Between The Male And Female Students Of The Experimental Sample In The Artistic Taste In The Post Test. This Is Clear From The Calculated T-Value Which Equals (1.075) I.E. Less Than The Tabulated T-Value Which Is Equal To (1.701) With Degree Of Freedom $=28$ Which Made The Difference Has No Statistical Significance At (0.05) Level As Shown In Tux $_{\text {(ne }}(6)$.

\section{Sixth :The Conclusions:}

The Two Researchers Concluded The Following:

1.The Artistic Taste For The Secondary Stage Students Can Be Developed By Using Analysis Of Designed Works For The Male And Female Students.

2.The Variation In The Sex Has No Influence In Developing The Artistic Taste By Analysis Of The Designed Works.

\section{Seventh: The Recommendations:}

The Two Researchers Recommended The Following:

1.Using The Analysis Of The Artistic Portraits In Teaching The Study Materials In The Plastic Arts Department Such As The Photographic Structure And The Artistic Criticism

2.Making The Subjects In Teaching The Artistic Education Lessons In The Secondary Stage Applicable For Both Male And Female Students.

\section{Eighth: The Proposals:}

The Two Researchers Proposed Performing The Scientific Study (Effectiveness Of Analysis Of Designing Works In Teaching The Photo Graphic Structure Rule For The Plastic Arts Students).

\section{Ninth: The References:}

Al-Basyoni , Mahmoud, "Origins Of The Artistic Education". Alam Al-Kitab, Al-Kuwait, 1985.

Jamagh , Hassan Jar Allah, "The Concept Of Self And Its Relationship With The Artistic Taste For The Essential Education College", Essential Education College Magazine. Volume 22, Issue 94, Year : 2016. 
Al-Gezany, Hassan Jar Allah, "The Artistic Taste For The Essential Education College And Its Relationship With Diverse Intelligence", Mustansiriyah University, Essential Education College, Un-Published Master Thesis), Year: 2010.

Al-Robeay, Oney Hady, "Relationship Between The Artistic Taste With The Artistic Education Material Study In The Iraqi Schools (University Of Babylon), Educational Studies, Issue: 32, Year: 2015.

Al-Shahin, Sultan Bin Hamad Bin Hamad, "Proposed Educational Program In The Tasting And The Artistic Criticism Based On The Interactive Means And The Scope Of Utilizing It In The Intermediate Stage", (Un-Published Master Thesis), Um Al-Kora University, Saudi Arabia Kingdom, Year: 2006.

Abd Al-Moneim, Ali Mohamed, "The Optical Culture", Dar Al-Boshra , Cairo, Year: 2000.

Freij, Amani Samir, "Effectiveness Of The Aesthetical Experience In Developing The Artistic Vision For The Artistic Education College Students", (Un-Published Master Thesis), College Of Education, Helwan University, Year:2000.

Al-Fadly, Sadia Mohsin Ayed, "The Portrait Culture And Its Role In Enriching The Artistic Taste For The Receiver", Um Al-Kora University, Saudi Arabia Kingdom, Year:2010.

Libd, Abd Al-Karim Mohamed, "Modern Trends In Teaching The Artistic Education, First Print, Al-Mekdad Print, Gazza, Year: 1999.

Al-Moneif, Abdallah And Salih, "The School Administration In The Light Of Tasks Of The Behavioral And Educational School's Manager", Second Print, Saudi Arabia Kingdom, The National King Fahad Library, Year: 1998.

Yehya, Mostafa Mahmoud, "The Communication Chain In The Artistic Taste Is A Feature In The Plastic Art In The Egyptian Environment", The Education Technology, A Series Of Studies And Research, Egypt, The Egyptian Society For The Education Technology, Year: 1992.

Rosenthal, Yadin, "Dictionary Of Progress Philosophy", Nscom, Press, London, Year: 1996. 